\section{Noe overfladisk om patologi}

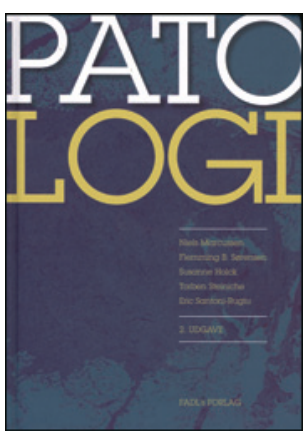

Niels Marcussen, Flemming B. Sørensen, Susanne Holck et al.

Patologi

2. utg. 757 s, tab, ill. København: FADL's

Forlag, 2013. Pris DKK 1100

ISBN 978-87-7749-618-9

Patologi er kommet i andre utgave. Denne læreboken er beregnet på alle som arbeider i helsevesenet - inkludert sykepleiestudenter og medisinstudenter.

Da mange symptomer kan relateres direkte til patologiske forandringer i celler og vev, har forfatterne forsøkt å sammenholde symptomer og patologiske funn. De gjennomgår sykdommer som man oftest møter i den kliniske hverdagen, og de gir et vesentlig bidrag til forståelsen av sykdommenes natur, diagnostikk og behandling. I alt er det 24 kapitler på 756 sider, og alle kapitlene er korte og konsise. Tekst og illustrasjoner er klart presentert. Det er rikelig med illustrasjoner, rammen er enkel og lettlest, og fargebildene har god oppløsning.

I innledningen beskriver forfatterne grundig faget patologi, celleskade og vevsreaksjoner og ikke neoplastiske vekstforandringer, fulgt av neoplastiske vekstforstyrrelser og onkopatologi. Det er lagt stor vekt på observerte kliniske symptomer. I de forskjellige organsystemenes patologi diskuteres de bakenforliggende patologiskanatomiske prinsippene. Kapitlene avsluttes med et kortfattet resymé i form av lettleste faktabokser.

Til tross for gode illustrasjoner blir kapitlene noe overfladiske, og de er heller ikke alltid oppdaterte. I forordet skriver forfatterne at patologisk anatomi og cytologi er helt sentralt for diagnostikk og behandling av mange pasienter, spesielt innen kreftområdet. De senere årene har det skjedd en rivende utvikling innen kreftdiagnostikk med multimodal og tverrfaglig tilnærming, som ikke er beskrevet. Dette gjelder bl.a. utvikling innen finnålscytologi kombinert med ultralydveiledning. De senere årenes utbredte tverrfaglige behandlingsteam kombinert med moderne molekylærbiologiske teknikker kommer ikke til sin rett her.

Boken er velskrevet og lett å orientere seg i. Stikkordregisteret er godt. Det sier seg selv at kapitlene blir noe overfladiske når forfatterne skal presentere sykdommenes natur, diagnostikk, behandling og symptomer på bare 756 sider. Boken vil være nyttig lesing for medisinstudenter, sykepleiestudenter og andre som arbeider i helsevesenet.

\section{Aasmund Berner}

Overlege, Avdeling for patologi

Oslo universitetssykehus, Radiumhospitalet

\section{Praktisk håndbok om ernæring hos barn}

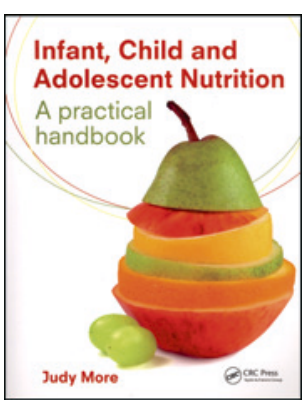

Judy More

Infant, child and adolescent nutrition

A practical handbook. 255 s, tab, ill. London:

CRC Press, 2013. Pris GBP 20

ISBN 978-1-4441-1185-9

Som tittelen sier er dette en praktisk håndbok i ernæring av barn fra fødsel til voksen alder. Men den er langt på vei også en komprimert lærebok. Målgruppene er så vel foreldre og andre omsorgspersoner, lærere og veiledere som profesjonelle helsearbeidere (barneleger, allmennpraktikere, helsesøstre, ernæringsfysiologer m.fl.) og studenter i helsefag.

De sju kapitlene omhandler ernæringsbehov og kostvaner, vurdering av vekt og næringsinntak, prenatal ernæring, ernæring av barn i ulike aldersgrupper (tre kapitler om henholdsvis spedbarn, førskolebarn og skolebarn) og ernæring ved kroniske tilstander som matallergi og intoleranse, obesitas, kroniske sykdommer og syndromer.

Hvert kapittel har en fyldig referanseliste. Det er en ordliste med definisjoner av fagterminologi og et appendiks med vekstkurver og kurver for kroppsmasseindeks (BMI) for gutter og jenter. Boken inneholder en rekke tabeller og figurer over alt fra kalori- og vitamininnhold i ulike næringsstoffer til ammeteknikk og forslag til sammensetning av måltider. Flere av kapitlene har utfordringer til leserne, spesielt studenter, med «activities» og svar på disse bakerst. Innholdsfortegnelsen er god.

Det mest slående er den didaktiske oppbyggingen og den delikate layouten. Det er utstrakt bruk av farger både i tekst, tabeller og figurer, noe som gjør innholdet luftig og tiltalende. Man får lyst til å bla og lese.

Allerede det fargerike omslaget gir signal om betydningen av frukt og grønt. Morsmelk markedsføres som den optimale ernæringen for spedbarn med introduksjon av fast føde ved 4-6 måneders alder. Også til premature barn har morsmelk en sentral plass. Således er det god overenstemmelse med norske tradisjoner og helsemyndighetenes anbefalinger på disse områdene. Det samme gjelder øvrige temaer.

Forfatteren vier mye plass til omtale av ernæringsforstyrrelser som anoreksi, bulimi og obesitas, ernæring ved kroniske sykdommer som cøliaki, cystisk fibrose, diabetes, kronisk tarmsykdom, kreft m.m., og feilernæring som viser seg som for eksempel tannkaries, jernmangel og D-vitaminmangel. Det er også en interessant omtale av ernæring knyttet til ulike kulturer og religiøse grupperinger.

Den praktiske vinklingen gjør boken anvendbar i dagliglivet for både foreldre og profesjonelle helsearbeidere. Boken har i tillegg teoretiske aspekter og er forskningsbasert. Den er skrevet av en ledende pediatrisk ernæringsfysiolog ved Plymouth University i England. Hun refererer til engelske retningslinjer så vel som Verdens helseorganisasjon (WHO). Den burde også være verdifull for vårt hjemlige miljø hvor ernæring i høy grad er et «hot topic».

Alf Meberg

Pensjonert barnelege

Tønsberg 